University of Nebraska - Lincoln

DigitalCommons@University of Nebraska - Lincoln

Agronomy \& Horticulture -- Faculty Publications

Agronomy and Horticulture Department

10-1980

\title{
Parent-Progeny Regression in Indiangrass: Inflation of Heritability Estimates by Environmental Covariances
}

\author{
Kenneth P. Vogel \\ University of Nebraska-Lincoln, kvogel1@unl.edu \\ Francis A. Haskins \\ University of Nebraska-Lincoln, fhaskins@neb.rr.com
}

H. J. Gorz

Follow this and additional works at: https://digitalcommons.unl.edu/agronomyfacpub

Part of the Plant Sciences Commons

Vogel, Kenneth P.; Haskins, Francis A.; and Gorz, H. J., "Parent-Progeny Regression in Indiangrass: Inflation of Heritability Estimates by Environmental Covariances" (1980). Agronomy \& Horticulture -Faculty Publications. 286.

https://digitalcommons.unl.edu/agronomyfacpub/286

This Article is brought to you for free and open access by the Agronomy and Horticulture Department at DigitalCommons@University of Nebraska - Lincoln. It has been accepted for inclusion in Agronomy \& Horticulture -Faculty Publications by an authorized administrator of DigitalCommons@University of Nebraska - Lincoln. 


\title{
Parent-Progeny Regression in Indiangrass: Inflation of Heritability Estimates by Environmental Covariances ${ }^{1}$
}

\author{
K. P. Vogel, F. A. Haskins, and H. J. Gorz ${ }^{2}$
}

\begin{abstract}
Families of two indiangrass [Sorghastrum nutans (L.) Nash] populations were used in this study with a family plot consisting of a parental clone and four half-sib progeny. The experimental design was a randomized complete block with two replications. The regression of offspring on the parent in the same plot was used to obtain heritability estimates in which environmental covariances might be expected to inflate the parent-offspring covariance. The regression of offspring in one replication with its parent in another replication, and vice versa, was used to obtain heritability estimates whereby environmental covariances should be minimized. Heritability estimates for heading date and plant height, which had high heritabilities, were similar for the two estimation techniques. Heritability estimates for forage yield and in vitro dry matter digestibility (IVDMD) appeared to be influenced by environmental covariances. Mean heritability estimates for forage yield and IVDMD for the three sets of data analyzed were 0.64 and 0.94 respectively, when parents and offspring in the same plot were used in the regression analyses and 0.28 and 0.42 respectively, when parents and offspring in different plots were used. Heritability estimates for forage protein content averaged 0.49 and were similar for both methods of estimation.
\end{abstract}

Additional index words: Sorghastrum nutans, Forage yield, Forage quality, In vitro digestibility, Genetic covariances.

${ }^{1}$ Contribution of the Dep. of Agronomy, Univ. of Nebraska, and AR, SEA, USDA. Published as Paper No. 5821, Journal Series, Nebraska Agric. Exp. Stn. Received 26 Sept. 1979.

${ }^{2}$ Research agronomist, AR, SEA, USDA; George Holmes professor of Agronomy, Univ. of Nebraska; and supervisory research geneticist, AR, SEA-USDA, Univ. of Nebraska, Lincoln, NE 68583 .
R EGRESSION of offspring on parents or on one $R$ parent is a method of estimating heritability commonly used by plant breeders. The covariance between a parent and its offspring produced by random mating is an estimate of one-half the additive genetic variance in a population $(3,5)$. The mean of several offspring is usually used as the offspring value. The covariance between offspring and parents is divided by the phenotypic variance of the parents to obtain the regression coefficient. Because the covariance between offspring and parent is only one-half the additive genetic variance, the regression coefficient is multiplied by two to obtain an estimate of narrow sense heritability (5).

Regression of offspring on parents to estimate heritability is based on the following assumptions $(3,4)$ : a) normal diploid and solely Mendelian inheritance, b) no environmental correlations among relatives, c) population in linkage equilibrium or no linkage among genes controlling the traits studied, d) the relatives are noninbred, e) the genetic population is mating at random. Heritability estimates obtained by parent-progeny regression are often used because the estimates obtained are valid both when the parents are selected on some basis and when they are chosen at random from a population (5).

The purpose of this paper is to demonstrate the inflationary effect that environmental covariances might have on heritability estimates if the second assump tion, i.e., no environmental correlations among relatives, is violated. In 1973, we began a quantitative genetic study on indiangrass, Sorghastrum nutans (L.) 
Nash. Our results from this study were used to estimate the effect of environmental covariances on heritabilities based on parent-progeny regression.

Indiangrass is a warm-season grass native to the prairies and plains of the United States (9) where it is used in pastures and rangelands for summer grazing. Limited genetic research on this grass has been reported although several varieties have been released. In our study we used two varieties that are adapted to the central Great Plains. 'Holt' was developed by mass selection from ecotypes collected in northeast Nebraska while 'Oto' was developed by mass and progeny selection from ecotypes collected in southeast Nebraska and northeast Kansas (7).

\section{MATERIALS AND METHODS}

In 1973, space-transplanted populations of a Holt $\times$ Oto synthetic and Oto indiangrass were sampled at panicle emergence for in vitro dry matter digestibility percentage (IVDMD) and for crude protein. Each nursery contained approximately 1,000 plants. The Holt $\times$ Oto synthetic was established from seed harvested from Holt plants exposed to Oto pollen in an open-pollinated Holt $\times$ Oto crossing block. Because Holt flowers 20 days earlier than Oto, it is doubtful if any crossing occurred and the Holt $\times$ Oto synthetic will be referred to as Holt. Plants in both nurseries were 2 years old when sampled. The Holt population was located at Lincoln, Nebraska, while the Oto population was located at Mead, Nebr., which is approximately $55 \mathrm{~km}$ northeast of Lincoln. In 1973, seed from open-pollinated plants was harvested from plants sampled from the two populations.

In 1974, a twice-replicated, space-transplanted half-sib progeny nursery was established at the Mead Field Laboratory with seedlings grown from open-pollinated seed from 41 Holt and 150 Oto parents that represented the high and low ends of the range in IVDMD, protein percentage, and heading date for the two populations. In 1975, two ramets (propagules) of the parental clones similar in size to the seedlings established the previous year were transplanted into the same nursery. A family plot consisted of a five-plant row with a parental ramet and four progeny seedlings. The parental ramet was at the end of the plot. Rows and plants within rows were spaced $1.1 \mathrm{~m}$ apart. The experimental design was a randomized complete block. Holt and Oto families were randomized together in the same nursery, but because of maturity differences were analyzed separately.

In 1976, heading date, height, and forage yields were determined on every plant in the nursery. The heading date was the day after 30 June when five panicles were emerging from the boot. Plant height was measured and the tillers bearing the first five panicles were cut approximately $5 \mathrm{~cm}$ above the base of the plant on the heading date. These tillers were dried, ground, and used for IVDMD and protein analyses. In 1976, the plants in the nursery were harvested for yield on 25,26 , and 27 October. In 1977 , only 30 of the better yielding Oto families were sampled for forage quality and harvested for yield using the same procedures as in 1976. In 1977, plants were harvested for yield on 18 October.

Each spring the nursery was cultivated by a rototiller that trimmed all clones back to a uniform size of $0.5 \mathrm{~m} \times 0.5 \mathrm{~m}$. Indiangrass has short rhizomes and spreads only moderately. At harvest, the individual plants were essentially $0.25 \mathrm{~m}^{2}$ microplots. The nursery was fertilized every spring with $112 \mathrm{~kg} / \mathrm{ha} \mathrm{N}$ and was sprayed with atrazine [2-chloro-4-(ethylamino)-6-(isopropylamino)-S-triazine] for weed control.

The Kjeldahl procedure (1) was used to determine percent N. Protein values are Kjeldahl $\mathbf{N} \times 6.25$. The Tilley and Terry (10) procedure was used to determine the IVDMD percentage.

Complete data sets were available on 36 Holt families and 146 Oto families for 1976 and for 30 Oto families for 1977, and only those families were used in the statistical analyses. Progeny means for each plot were used as the offspring values. Since the parents and progeny in the same plot were expected to be environmentally correlated, the regressions of offspring mean on the parent clone in the same family plot were calculated
Table 1. Regression of half-sib progeny plot means on parent plants in the same plot and on parents in different plots in an adjacent replication for two indiangrass populations. $\dagger$

\begin{tabular}{|c|c|c|c|c|c|c|c|}
\hline \multirow{2}{*}{$\begin{array}{l}\text { Popula- } \\
\text { tion }\end{array}$} & \multirow[b]{2}{*}{ Trait } & \multicolumn{3}{|c|}{ Same plot } & \multicolumn{3}{|c|}{ Different plot } \\
\hline & & b & $s_{b}$ & $\operatorname{cov}$ & b & $s_{b}$ & cov \\
\hline $\begin{array}{l}\text { Holt } \\
\quad 1976\end{array}$ & $\begin{array}{l}\text { Heading } \\
\text { Height } \\
\text { Yield } \\
\text { Protein \% } \\
\text { IVDMD\% }\end{array}$ & $\begin{array}{l}0.72^{* *} \\
0.52^{* *} \\
0.28^{* *} \\
0.42^{* *} \\
0.52^{* *}\end{array}$ & $\begin{array}{l}0.04 \\
0.06 \\
0.10 \\
0.08 \\
0.08\end{array}$ & $\begin{array}{c}118.92 \\
154.76 \\
.9,899 \\
0.2529 \\
. \quad 3.2341\end{array}$ & $\begin{array}{l}0.71^{* * *} \\
0.46^{* *} \\
0.19^{*} \\
0.41^{* *} \\
0.17\end{array}$ & $\begin{array}{l}0.05 \\
0.06 \\
0.09 \\
0.08 \\
0.10\end{array}$ & $\begin{array}{c}117.17 \\
138.73 \\
6,764 \\
0.2488 \\
1.0761\end{array}$ \\
\hline $\begin{array}{l}\text { Oto } \\
1976\end{array}$ & $\begin{array}{l}\text { Heading } \\
\text { Height } \\
\text { Yield } \\
\text { Protein \% } \\
\text { IVDMD\% }\end{array}$ & $\begin{array}{l}0.49^{* *} \\
0.33^{* *} \\
0.22^{* *} \\
0.14^{* *} \\
0.44^{* *}\end{array}$ & $\begin{array}{l}0.03 \\
0.04 \\
0.04 \\
0.02 \\
0.03\end{array}$ & $\begin{array}{c}30.36 \\
93.91 \\
10,958 \\
0.1125 \\
3.3164\end{array}$ & $\begin{array}{l}0.46^{* *} \\
0.25^{* *} \\
0.08^{*} \\
0.11^{* *} \\
0.14^{* *}\end{array}$ & $\begin{array}{l}0.03 \\
0.04 \\
0.04 \\
0.03 \\
0.04\end{array}$ & $\begin{array}{c}28.58 \\
71.25 \\
4,093 \\
0.0873 \\
0.0846\end{array}$ \\
\hline $\begin{array}{l}\text { Oto } \\
1976 \\
\text { and } \\
1977\end{array}$ & $\begin{array}{l}\text { Heading } \\
\text { Heightt } \\
\text { Yield } \\
\text { Protein \% } \\
\text { IVDMD\% }\end{array}$ & $\begin{array}{l}0.63^{* *} \\
0.38^{* *} \\
0.46^{* *} \\
0.22^{* *} \\
0.45^{* *}\end{array}$ & $\begin{array}{l}0.07 \\
0.07 \\
0.09 \\
0.07 \\
0.07\end{array}$ & $\begin{array}{c}20.34 \\
80.30 \\
\mathbf{8 , 9 4 6} \\
\mathbf{0 . 0 9 4 4} \\
1.9918\end{array}$ & $\begin{array}{l}0.57^{* *} \\
0.19^{*} \\
0.15 \\
0.22^{* *} \\
0.33^{* *}\end{array}$ & $\begin{array}{l}0.08 \\
0.09 \\
0.11 \\
0.07 \\
0.08\end{array}$ & $\begin{array}{c}18.61 \\
40.65 \\
2,978 \\
0.0946 \\
1.4699\end{array}$ \\
\hline
\end{tabular}

*,** Indicate significance at the 0.05 and the 0.01 levels of probability, respectively, for the hypothesis that $b=0$. $\quad+b=$ regression coefficient, $s_{b}=$ the standard error of the regression coefficient, $\operatorname{cov}=$ the parent-progeny covariance, heritability $=2 \mathrm{~b}$. the different plot regression coefficient lies outside the $95 \%$ confidence interval of the same plot regression coefficient.

using all family plots in the experiment for each trait to provide an estimate of heritability in which the parent-offspring covariances might be inflated by environmental covariances. The regressions of offspring in replication 1 with parents in replication 2 , and vice versa, were calculated to provide estimates of heritability in which parent-offspring covariances theoretically would not be expected to be biased by environmental covariances. The Holt 1976, Oto 1976, and the Oto 1976 and 1977 data sets were analyzed separately. Mean values over years for each parent plant and progeny row were used for the Oto 1976 and 1977 data set. The total degrees of freedom for the regression analysis for each data set is $2 n$ where $n$ is the number of families in that set.

\section{RESULTS AND DISCUSSION}

The covariances between parents and progenies in the same and different plots were similar for heading date, plant height (except for the Oto 1976 to 1977 data set), and protein percentage for all three data sets (Table 1). The environmental covariances for these three traits in this experiment either were small or did not differ in the two methods of estimation. Consequently, the regression coefficients (b) calculated by the two different regression procedures, i.e., same plot or different plot, were very similar for each population for these three traits.

The covariances between parents and progenies in the same plots were considerably larger than the covariances between parents and progenies in different plots for yield and IVDMD percentage for all three data sets. We believe that these differences were due to environmental covariances. Theoretically, the covariance values for parents and progenies in the same plot include parent-progeny environmental covariances and if so, the regression coefficients for yield and IVDMD percentage determined by the regression of offspring on parents in the same plot are probably inflated by environmental covariances. Assuming that there were no negative environmental covariances between replications, theoretically the regression coefficient determined by the regression of parents and offspring in different plots were not inflated by en- 
vironmental covariances and should provide more valid estimates of heritability.

It would be expected that traits with low heritability would be affected more by environmental covariances than would highly heritable traits. As shown by the 1976 data for both Holt and Oto (Table 1), this expectation was realized in a number of instances in the present study. Measured by "different plot" (DP) regression coefficients, heritabilities for yield and IVDMD were low for these two populations, and "same plot" (SP) regression coefficients were considerably higher than DP values. For heading date and height, on the other hand, heritabilities were higher and differences were less pronounced than for yield and IVDMD.

Considering the 30 Oto families that were sampled in both 1976 and 1977, DP heritabilities were lowest for height and yield, and differences between SP and DP values were largest for these traits. For reasons that are not understood, heritabilities for protein percentage varied rather widely over the three populations, but for each population, the DP value was approximately equal to the SP value. The large regression coefficients observed for heading date may have been due to naturally occurring assortative mating among plants of similar maturity within the populations.

A simple general model can be used to explain how environmental covariances can be included in the covariance between parents and offspring. The phenotype of a parent may be expressed as: $P_{p}=G_{p}$ $+E_{p}$ and the phenotype of its offspring is $P_{o}=G_{o}+$ $E_{o}$ where $P$ is the phenotypic value of an individual, $\mathrm{G}=$ the genotypic value, and $\mathrm{E}$ is the environmental deviation, as defined by Falconer (5). The parentprogeny covariance is then $\sigma_{\mathrm{op}}=\sigma_{\mathrm{g}_{\mathrm{op}}}+\sigma_{\mathrm{g}_{\mathrm{p}} \mathrm{e}_{\mathrm{o}}}+$ $\sigma_{g_{o} e_{p}}+\sigma_{e_{o p}}$ or more simply $\sigma_{o p}=\sigma_{g_{o p}}+2 \sigma_{\mathrm{ge}_{o p}}+$ $\sigma_{e_{o p}}$. The symbols $\sigma_{o p}, \sigma_{g_{o p}}, \sigma_{g e_{o p}}$, and $\sigma_{e_{o p}}$ refer to the phenotypic covariance between offspring and parent, genetic covariance between offspring and parent, covariance between genotypic and environment, and environmental covariance between parent and offspring, respectively. If families are randomized, the term $\sigma_{\mathbf{g e}_{0 \mathrm{p}}}$ should be equal to zero since families and environments are not correlated (5). If parents and progenies are likewise randomized then $\sigma_{e_{\text {op }}}$ will also probably be equal to zero and $\sigma_{\mathrm{op}}=\sigma_{\mathrm{g}_{\mathrm{op}}}$. If parents and progenies are included in the same plot then $\sigma_{o p}$ $=\sigma \mathrm{g}_{\mathrm{op}}+\sigma_{\mathrm{e}}$ which can inflate heritability estimates if $\sigma e_{o p}$ is significant. Since the families in our experiment were randomized, $\sigma_{\mathbf{g e}_{\mathbf{o p}}}$ should be equal to zero and estimates of environmental covariance can be obtained by subtracting the SP covariances from the DP covariances.

Randomization of parent plants within a family plot would probably have had little effect on the results since parents and progenies are expected to be environmentally correlated when they are in the same plot regardless of the position of the parent plant in the family plot. We placed the parent plant on the end of the plots primarily to simplify records and data analyses.

Environmental covariances are probably positive for most agronomic crops in fields where soils, slope, and drainage are fairly uniform as they were in this study. Situations may exist, however, where this may not be true, and if so, negative environmental covariances could exaggerate the differences between same plot and different plot regressions.

Although we did not exhaustively search the literature, we found four papers on forage grasses in which the covariances between relatives probably contained environmental covariances since the relatives used in the analyses were in the same plot $(2,6,8,9)$. Some of the heritabilities and correlations between relatives reported in these papers may have been inflated by environmental covariances.

In summary, our data suggest that environmental covariances can have a significant inflationary effect on heritability estimates determined by parent-progeny regression unless the experiment is designed or analyzed to avoid this effect. If a breeder wishes to have parents and progenies in the same plot for comparison purposes, our results suggest that the technique of determining the covariances between parents and progenies in different replications might be used to reduce the bias caused by covariances.

\section{ACKNOWLEDGMENTS}

The authors thank Drs. C. O. Gardner and W. A. Compton for their comments and helpful suggestions on the research reported in this manuscript.

\section{REFERENCES}

1. Association of Official Agricultural Chemists. 1960. Official methods of analyses of the A.O.A.C. 9th ed. A.O.A.C. Washington, DC.

2. Barker, R. E., and A. W. Hovin. 1974. Inheritance of indole alkaloids in reed canarygrass (Phalaris arundinacea L.). I. Heritability estimates for alkaloid concentration. Crop Sci. 14:50-53.

3. Cockerham, C. Clark. 1963. Estimation of genetic variances. p. 53-94. In W. D. Hanson and H. F. Robinson (ed.) Statistical genetics and plant breeding. NAS-Natl. Res. Coun. Pub. 982.

4. Dudley, J. W., and R. H. Moll. 1969. Interpretation and use of estimates of heritability and genetic variances in plant breeding. Crop Sci. 9:257-262.

5. Falconer, D. S. 1960 . Introduction to quantitative genetics. Ronald Press Co., N. Y.

6. Grissom, D. B., and R. R. Kalton. 1956. Inheritance of combining ability for forage traits in bromegrass (Bromus inermis Leyss.). Agron. J. 48:289-293.

7. Hanson, A. A. 1972. Grass varieties in the United States. USDA Agric. Handb. no. 170.

8. Hawk, V. B., and C. P. Wilsie. 1952. Parent-progeny yield relationships in bromegrass, Bromus inermis Leyss. Agron. J. 44:112-118.

9. Kalton, R. R., A. G. Smut, and R. C. Leffel. 1952. Parentinbred progeny relationships of selected orchardgrass clones. Agron. J. 44:481-486.

10. Tilley, J. A., and R. A. Terry. 1963. A two-stage technique of the in vitro digestion of forage crops. J. Brit. Grassl. Soc. 18:104-111. 